\title{
PENGARUH KOMBINASI SENAM KAKI DAN AROMATERAPI TERHADAP ABI DAN TINGKAT STRES PADA PENDERITA DM DI PUSKESMAS JAJAG
}

\section{The Influence Of Combination Of Foot Gymnastic And Aromatheraphy To Abi And Stress Levels In Dm Patients In Jajag Health Center}

\author{
Hirdes Harlan Yuanto ${ }^{1}$, Abu Bakar ${ }^{2}$, Puji Astuti ${ }^{3}$ \\ ${ }^{1 .}$ Mahasiswa Universitas Nahdlatul Ulama Surabaya \\ 2. Universitas Airlangga Surabaya \\ ${ }^{3 .}$ Universitas Nahdlatul Ulama Surabaya \\ ns.harlan86@gmail.com
}

\begin{abstract}
ABSTRAK
Ankle Brachial Index (ABI) merupakan salah satu pemeriksaan dini pada untuk mengetahui insufisiensi arteri sebagai salah satu komplikasi dari diabetes mellitus. Dimana insufisiensi arteri merupakan keadaan pembuluh darah yang berkurang aliran darah yang berakibat iskemia jaringan. Selain itu pada pasien dengan diabetes mellitus juga dapat timbul permasalahan stress sebagai dampak dari penyakit menahun yang dialami. Salah satu metode penatalaksanaan kedua kondisi diatas adalah kombinasi senam kaki diabetic dengan aroma terapi. Penelitian ini bertujuan menganalis pengaruh kombinasi senam kaki dan aromaterapi terhadap ankle brachial index dan tingkat stres pada penderita diabetes mellitus.

Penelitian ini menggunakan desain pre and post test group design with control group. Populasi penelitian ini pasien di wilayah kerja Puskesmas Jajag. Tehnik sampling purposive sampling dengan besar sampel 32 orang. Alat pengumpulan data kuesioner dan observasi, dianalisa dengan uji wilcoxon. Keputusan diambil dengan membandingkan nilai probabilitas $\mathrm{p}$ value $<0.05$.

Hasil penelitian menunjukkan uji Wilcoxon ada pengaruh senam kaki dan aromaterapi terhadap nilai ABI dengan $p$ value 0.004 dan ada pengaruh senam kaki dan aromaterapi terhadap tingkat stress dengan $p$ value 0.001. Senam kaki adalah kegiatan atau latihan yang dilakukan oleh pasien DM untuk mencegah terjadinya luka dan membantu melancarkan peredaran darah bagian kaki. Senam kaki dapat memperbaiki sirkulasi darah dan mencegah terjadinya kelainan bentuk kaki. Sementara itu Aroma terapi dengan menggunakan minyak essensial yang dinilai dapat membantu mengurangi bahkan mengatasi gangguan psikologis dan gangguan rasa nyaman seperti cemas, stress, depresi, dan sebagainya

Untuk meningkatkan nilai abi maka diharapkan pasien untuk rutin melakukan senam kaki diabetic. Sementara itu untuk meningkatkan relaksasi dan menurunkan tingkat stress, pasien diabetes mellitus dapat melakukan aktifitas aroma terapi.
\end{abstract}

Kata kunci: ABI, tingkat stress, DM

\section{ABSTRACT}

Ankle Brachial Index is one of the early checks on to determine arterial insufficiency. Where arterial insufficiency is a state of blood vessels that decreases blood flow resulting in tissue ischaemia. Aromatherapy is a therapeutic action by using essential oils that are beneficial to improve the physical and psychological conditions so that the better.This study aims to analyze the influence of combination of foot exercises and aromatherapy to ankle brachial index and stress level in people with diabetes mellitus.

This research uses pre and post design group design with control group. The population of this study were patients in the working area of Puskesmas Jajag. Sampling technique purposive sampling with a large sample of 32 people. Data collection tool of questionnaire and observation, analyzed by wilcoxon test. Decision is made by comparing probABIlity value p value $<0.05$.

The results showed Wilcoxon test there is influence of foot and aromatherapy exercises on the value of ABI with $p$ value 0.004 and there is influence of foot and aromatherapy gymnastics to stress level with $p$ value 0.001. Foot exercises are activities or exercises performed by DM patients to prevent injuries and help smooth blood circulation of the legs. Gymnastics can improve blood circulation and prevent foot deformities. Meanwhile, Aroma therapy by using essential oils that are assessed can help reduce even overcome psychological disturbances and discomforts such as anxiety, stress, depression, and so on.

To increase the value of $A B I$ it is expected the patient to routinely perform diabetic foot exercises. Meanwhile, to increase relaxation and reduce stress levels, patients with diabetes mellitus can perform aroma therapy activities.

Keywords: ABI, stress level, DM 


\section{PENDAHULUAN}

Diabetes Mellitus bisa menyerang segala usia yang ditandai sering mengeluh buang air kecil ketika malam hari, gampang lapar, berat badan turun drastis, gampang letih dan lesu. Tanda-tanda tersebut bisa terjadi jika kadar gula yang beredar dalam darah tinggi atau Hiperglikemia kronik dan gangguan metabolik diabetik melitus lainnya akan menyebabkan kerusakan jaringan dan organ, seperti mata, ginjal, syaraf, dan sistem vaskular. Kerusakan jaringan yang terlokalisir yang disebabkan adanya penekanan jaringan lunak yang menonjol atau biasa disebut ulkus diabetikum. Ulkus diabetikum adalah salah satu penyulit pada pasien diabetes yang menyerang kulit ditandai rasa kesemutan (Soegondo, 2009).

Sebagian besar seseorang yang telah didiagnosa diabetes mellitus akan mengalami banyak perubahan dalam hidup. Ada yang jadi takut, cemas, panik, marah, dan ada pula yang memberontak (Tandra, 2013). Hasil penelitian Murdiningsih (2013) terdapat 47\% penderita diabetes yang mengalami kecemasan akibat penyakitnya. Berdasarkan penelitian Murdiningsih (2013) tentang pengaruh kecemasan terhadap gula darah pasien diabetes mellitus, didapatkan hasil sebanyak $47 \%$ responden cemas dengan kadar gula $\geq 200 \mathrm{mg} / \mathrm{dl}$. Salah satu gangguan secara fisiologis dan fisiologis yang disebabkan oleh perubahan dan tuntutan kehidupan adalah stress (Dalami, Ermawati. 2010).

Ankle Brachial Index merupakan salah satu pemeriksaan dini pada kaki hal ini penting dilakukan untuk mengetahui insufisiensi arteri. Dimana insufisiensi arteri sendiri merupakan keadaan pembuluh darah yang berkurang aliran darah arteri yang berakibat iskemia jaringan (Nasution, dkk 2010). Apabila jaringan perifer telah iskemia bisa dimungkinkan akan berakibat amputasi. Penelitian tentang gambaran sirkulasi darah pada kaki penderita DM telah dilakukan oleh Laksmi, Ayu, Mertha, Widianah (2009) di Puskesmas II Denpasar Barat Propinsi Bali, menunjukan hasil: ABI dengan kategori borderline (65\%), ABI dengan kategori normal (30\%), ABI dengan kategori iskemia berat $(5 \%)$, dan $\mathrm{ABI}$ dengan kategori iskemia kaki kritis $(0 \%)$.

Angka kejadian diabetes Mellitus pada penderita dewasa di Asia Tenggara terdapat kecenderungan meningkat dari 4,1 $\%$ pada era tahun 1980 an, meningkat menjadi 8,6\% di tahun 2014 dan diprediksi akan meningkat sampai 80 juta pada tahun 2025 . Jumlah ini merupakan yang tertinggi di dunia (Searo, 2016). Tahun 2015, Indonesia menduduki peringkat ke-7 di dunia untuk angka kejadian penyakit diabetes mellitus tertinggi di dunia diikuti oleh China, India, Amerika Serikat, Brazil, Rusia, dan Meksiko dengan jumlah estimasi orang dengan diabetes sebesar 10 juta (Nam Han Cho, 2017). Berdasarkan Riskesdas tahun 2013, Jawa Timur adalah satu dari beberapa daerah di Indonesia dengan angka kejadian kencing manis sebesar $2,1 \%$. Menurut data Dinkes Prov Jatim (2012) dari 10 penyakit yang paling banyak di IRJ RS tipe B adalah DM dan merupakan penyakit terbanyak dengan urutan nomor dua setelah tekanan darah tinggi yaitu 102.399 kasus. Berdasarkan data Dinkes Kab. Banyuwangi angka kejadian baru pasien Diabetes Mellitus tahun 2013 sebesar 28\% dan mengalami kenaikan di tahun 2014 sebesar 31,9\%. Diabetes Mellitus merupakan penyakit dengan angka kejadian terbanyak nomor 2 di Jajag kabupaten Banyuwangi setelah stroke hal ini bisa dilihat dari data di Puskesmas Jajag dari tahun 2015 sebanyak 25 kasus tahun 2016 sebanyak tahun 2017 sebanyak

Meningkatnya jumlah penderita diabetes mellitus dipicu beberapa faktor diantaranya adalah faktor keturunan/genetik, obesitas, perubahan gaya hidup, kesalahan pola makan, obat-obatan dapat mempengaruhi gula darah, aktifitas yang kurang, penuaan, gravida, merokok dan stress (Muflihatin, 2015). Ada banyak hal pencegahan diabetes mellitus yang di jalankan oleh Pemkab Banyuwangi, akan tetapi angka kejadian baru penyakit diabetes mellitus cenderung meningkat. Kenaikan tersebut dapat dipicu oleh banyak hal diantaranya kepatuhan yang kurang saat menjalankan program empat pilar pengendalian diabetes mellitus yaitu: edukasi; diet; oleh raga dan pemberian obatobatan.

Terapi yang bisa dilaksanakan saat komplikasi telah terjadi yaitu dengan mengontrol glukosa darah untuk menghindari komplikasi yang lebih jelek. Penanganan neurophaty ini dapat dilakukan melalui tiga 
hal yaitu (1) penyuluhan atau pemberian nasehat; (2) pengobatan nyeri; dan (3) perawatan kaki (Tandra, 2013). Pertama dengan penyuluhan kesehatan tentang diet diabetes yang benar. Kedua dengan pengobatan nyeri diabetes seperti anti depresan trisiklik, Opiat, dan obat-obat topikal. Ketiga dengan perawatan kaki, perawatan kaki dapat dilakukan dengan memeriksa adanya perlukaan dan gejala infeksi, setiap hari lakukan perawatan kaki, berikan pelembab, melakukan senam kaki. Senam Kaki merupakan salah satu jenis komplementari terapi yang dapat digunakan untuk mencegah terjadinya komplikasi diabetes yaitu ulkus diabetikum. Pencegahan kaki diabetik dapat dengan menekankan kondisi gizi dan gula darah, kontrol vaskular dengan cara melakukan latihan kaki dan pemeriksaan vaskular non-invasif diantaranya $A B I$, toe pressure, dan ankle pressure secara rutin, serta modifikasi faktor resiko seperti berhenti merokok dan penggunaan alas kaki khusus (Ganong, 2008). Pemantauan kadar gula dalam tubuh serta pengobatan menggunakan suntik insulin merupakan salah satu cara pencegahan diabetes Mellitus. Pencegahan ini semuanya dilakukan oleh pasien di wilayah desa Jajag yang mendapat terapi tetapi masih ditemukan kejadian kaki diabetik.

Banyak cara dilakukan untuk menghilangkan atau menurunkan tingkat stres pada penderita Diabetes Mellitus cara tersebut antara lain dengan tindakan farmakologis dan non farmakologis. Namun tindakan farmakologis dalam jangka panjang akan berefek pada kesehatan organ dalam terutama ginjal sebagai filter tubuh maka alternatif yang lain adalah tindakan non farmakologis diantaranya sering berdzikir, mendengarkan musik klasik, menghirup aromaterapi, senam yoga dan lain-lain (Tamimy, 2015).

Seiring berkembangnya daya pikir manusia pemilihan tindakan non farmakologi menjadi trend baru yang bisa dikembangkan dan bisa jadi cara alternatif dalam mengatasi stress ataupun menurunkan tingkat stress. Aromaterapi banyak digunakan sebagai perawatan alternatif untuk berbagai kondisi kesehatan. Tidak mengherankan jika semakin lama semakin mudah untuk menemukan berbagai produk aromaterapi yang berkhasiat bagi tubuh. Sebuah studi yang dilakukan oleh
Maharani (2012) di sebuah perguruan tinggi swasta di Yogyakarta, bahwa sebanyak 28 mahasiswa tingkat akhir mengalami stress sedang $78 \%$ diantaranya menggunakan aromaterapi mencegah masalah psikolgis.

Hasil penelitian (Nathaniel Clark, 2009) menunjukkan bahwa dilakukan senam kaki secara teratur dapat mencegah kenaikan kadar gula dalam darah dan bisa menurunkan kadar gula darah, serta meningkatkan ABI yang diartikan sangat efektif dalam perbaikan sirkulasi darah pada kaki pasien Diabetes Mellitus tipe II. Penelitian yang lainnya menyebutkan bahwa aromaterapi juga dapat menurunkan angka stres dan meningkatkan skor ABI. Beberapa penelitian tidak ditemukan adanya penggabungan terapi senam kaki kombinasi aromaterapi yang dilakukan bersamaan untuk mencegah kaki diabetik.

\section{METODE}

Penelitian ini menggunakan desain penelitian Quasy-Experimental dengan pendekatan pre post test control group design. Populasi pada penelitian ini adalah penderita Diabetes Mellitus tipe 1 di Desa Jajag sejumlah 100 orang (data observasi peneliti). Sampel dalam penelitian ini adalah penderita Diabetes Mellitus tipe 1 di Desa Jajag sejumlah 32 orang dengan kriteria 16 orang kelompok perlakuan dan 16 orang kelompok kontrol. Teknik pengambilan sampel yang dilakukan dalam penelitian ini menggunakan non probability sampling dengan teknik consecutive sampling. Sampel diambil apabila memenuhi kriteria inklusi dan eksklusi. Kriteria inklusi dalam penelitian ini adalah umur kurang dari 50 tahun, menderita DM kurang dari 6 bulan, Diabetes Mellitus tipe 1, tidak memiliki masalah luka dikaki, tanda- tanda vital : TD: $>100 / 50 \mathrm{mmHg}$ atau $<180 / 100 \mathrm{mmHg}$, nadi 60-100 x/mnt, pernafasan $16-20 \mathrm{x} / \mathrm{mnt}$, hemoglobin > 9,5 g/dl, kesadaran Composmentis. Kriteria eksklusi dalam penelitian ini adalah memiliki riwayat jantung yang tidak stabil ( angina, gagal jantung kongestif, miokarditis, stenosis aorta berat, aritmia yang membutuhkan perawatan), ada riwayat rawat inap 3 bulan terakhir, lansia, memiliki masalah luka dikaki, alergi dengan bau-bauan terutama lavender. 
Data penelitian diperoleh dengan menggunakan instrumen pengumpulan data pada variabel independent pelaksanaan senam kaki diabetes menggunakan modul latihan dan menghirup uap yang berasal dari tungku pemanas aromaterapi dan untuk mengukur variabel dependent nilai $\mathrm{ABI}$ dan tingkat stress menggunakan lembar observasi berbentuk kuisioner DASS yang telah tersedia. Kuesioner yang digunakan pada penelitian menggunakan kuesioner yang sudah tervalidasi yaitu DASS 42, sehingga tidak perlu dilakukan uji validitas dan reabilitas karena memiliki nilai validitas dan reliabilitas dengan nilai 0,91 yang dilakukan oleh Crawford \& Henry (2003).

Penelitian ini dilakukan selama 4 minggumelakukan senam kaki diabetes mellitus dengan benar dan melakukan senam kaki didampingi peneliti atau asisten, $5 \mathrm{X} /$ Minggu selama 4 minggu dengan latihan 30 menit sekali senam dengan gerakan utama pada daerah persendian. Selama gerakan ini disamping kanan/kiri pasien diberi tungku aromaterapi. Analisa data menggunakan analisa deskriptif dan analisa inferensial menggunakan uji Wilcoxon dan U Mann Whitney dengan nilai kemaknaan $\mathrm{p}$ value < 0.05 .

\section{HASIL}

Berdasarkan hasil penelitian yang sudah dilakukan pada pasien DM di wilayah kerja Puskesmas Jajag sebagai berikut:

Tabel 1 Analisis ABI pada penderita diabetes mellitus sebelum dan sesudah dilakukan tindakan intervensi pada kelompok intervensi dan kontrol di Puskesmas Jajag tahun 2018

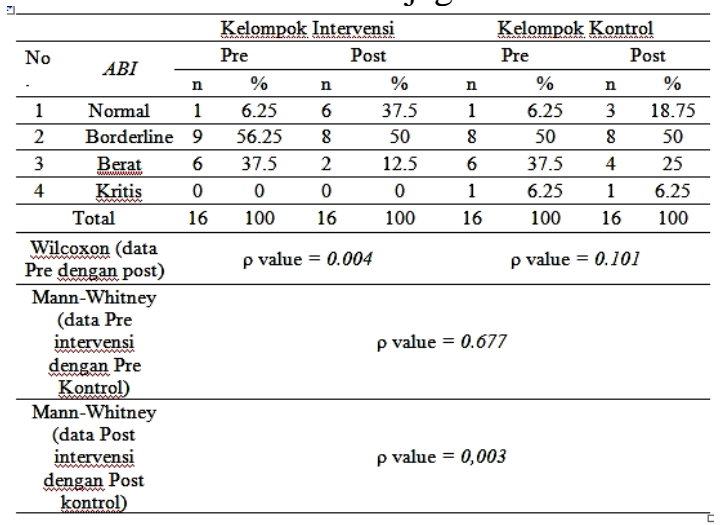

Sumber: data primer 2018
Berdasarkan tabel 1 diketahui bahwa, dari 16 reponden kelompok intervensi didapatkan sebagian besar memiliki kategori ABI pre test borderline sebanyak 9 orang $(56,25 \%)$ dan setelah diberikan intervensi separuh responden memiliki kategori $\mathrm{ABI}$ borderline sebanyak 8 orang (50\%). Sementara itu dari 16 responden kelompok control didapatkan separuh responden memiliki kategori ABI pre test borderline sebanyak 8 orang (50\%) dan separuh responden memiliki nilai post test borderline sebanyak 8 orang $(50 \%)$.

Berdasarkan analisis statistik pre test dengan post test ABI pada kelompok intervensi dengan menggunakan uji Wilcoxon diperoleh hasil $\rho$ value 0.004 , lebih kecil dari $\alpha$ 0.05. Sementara itu analisis statistik pre test dengan post test pada kelompok control dengan menggunakan uji Wilcoxon diperoleh hasil $\rho$ value 0.101 . Dari hasil tersebut dapat disimpulkan bahwa Ho ditolak dan $\mathrm{Hi}$ diterima yang artinya ada pengaruh tindakan intervensi terhadap nilai ABI pada pasien diabetes mellitus.

Tabel 2 Analisis tingkat stress pada penderita diabetes mellitus sebelum dan sesudah dilakukan tindakan intervensi pada kelompok intervensi dan kontrol di Puskesmas Jajag tahun 2018

\begin{tabular}{|c|c|c|c|c|c|c|c|c|c|}
\hline \multirow{3}{*}{ No. } & \multirow{3}{*}{ Stress } & \multicolumn{4}{|c|}{ Kelompok Intervensi } & \multicolumn{4}{|c|}{ Kelompok Kontrol } \\
\hline & & \multicolumn{2}{|c|}{ Pre } & \multicolumn{2}{|c|}{ Post } & \multicolumn{2}{|c|}{ Pre } & \multicolumn{2}{|c|}{ Post } \\
\hline & & $\mathrm{n}$ & $\%$ & n & $\%$ & $\mathbf{n}$ & $\%$ & $\mathrm{~N}$ & $\%$ \\
\hline 1 & Normal & 1 & 6.25 & 7 & 43.75 & 2 & 12.5 & 3 & 18.75 \\
\hline 2 & Ringan & 5 & $\begin{array}{c}31.2 \\
5\end{array}$ & 7 & 43.75 & 4 & 25 & 5 & 31.25 \\
\hline 3 & Sedang & 7 & $\begin{array}{c}43.7 \\
5\end{array}$ & 2 & 12.5 & 8 & 50 & 6 & 37.5 \\
\hline 4 & Berat & 3 & $\begin{array}{c}18.7 \\
5\end{array}$ & 0 & 0 & 2 & 12.5 & 2 & 12.5 \\
\hline \multirow[t]{2}{*}{5} & $\begin{array}{c}\text { Sangat } \\
\text { berat }\end{array}$ & 0 & 0 & 0 & 0 & 0 & 0 & 0 & 0 \\
\hline & otal & 16 & 100 & 16 & 100 & 16 & 100 & 16 & 100 \\
\hline \multicolumn{2}{|c|}{$\begin{array}{l}\text { Wilcoxon (data Pre } \\
\text { dengan post) }\end{array}$} & \multicolumn{4}{|c|}{$\rho$ value $=0.001$} & \multicolumn{4}{|c|}{$\rho$ value $=0.444$} \\
\hline \multicolumn{2}{|c|}{$\begin{array}{l}\text { Mann-Whitney } \\
\text { (data Pre intervensi } \\
\text { dengan Pre } \\
\text { Kontrol) }\end{array}$} & \multicolumn{4}{|c|}{$\rho$ Value $=0.595$} & & & & \\
\hline \multicolumn{2}{|c|}{$\begin{array}{l}\text { Mann-Whitney } \\
\text { (data Post } \\
\text { intervensi dengan } \\
\text { Post kontrol) }\end{array}$} & \multicolumn{8}{|c|}{$\rho$ Value $=0.081$} \\
\hline
\end{tabular}

Sumber: data primer 2018

Berdasarkan tabel 2 diketahui bahwa, dari 16 reponden kelompok intervensi hamper setengah responden memiliki kategori tingkat stress pretest sedang sebanyak 7 orang $(43,75 \%)$ dan setelah dilakukan intervensi hamper setengah responden kategori tingkat stress normal dan ringan masing-masing 7 orang $(43,75 \%)$. Sementara itu dari 16 reponden kelompok control separuh responden memiliki kategori 
tingkat stress pre test sedang sebanyak 8 orang $(50 \%)$ dan setelah dilakukan post test hamper setengah responden kategori tingkat stress sedang sebanyak 6 orang $(37,5 \%)$.

Berdasarkan analisis statistik pre test dengan post test tingkat stress pada kelompok intervensi dengan menggunakan uji Wilcoxon diperoleh hasil $\rho$ value 0.001 , lebih kecil dari $\alpha$ 0.05. Sementara itu analisis statistik pre test dengan post test tingkat stress pada kelompok kontrol dengan menggunakan uji Wilcoxon diperoleh hasil $\rho$ value 0.444. Dari hasil tersebut dapat disimpulkan bahwa Ho ditolak dan $\mathrm{Hi}$ diterima yang artinya ada pengaruh tindakan intervensi terhadap tingkat stress pada pasien diabetes mellitus.

\section{PEMBAHASAN}

1. Analisis ankle brachial index pada penderita diabetes mellitus sebelum dan sesudah dilakukan tindakan kombinasi senam kaki dan aromaterapi pada kelompok intervensi dan kontrol.

Dari table 1 diketahui bahwa, analisis statistik pre test dengan post test ABI pada kelompok intervensi dengan menggunakan uji Wilcoxon diperoleh hasil $\mathrm{P}$ value 0.004 , lebih kecil dari $\alpha$ 0.05 . Sementara itu analisis statistic pre test dengan post test pada kelompok kontrol dengan menggunakan uji Wilcoxon diperoleh hasil $\mathrm{P}$ value 0.101 . Dari hasil tersebut dapat disimpulkan bahwa Ho ditolak dan Hi diterima yang artinya ada pengaruh tindakan kombinasi senam kaki dan aromaterapi terhadap nilai $\mathrm{ABI}$ pada pasien diabetes mellitus.

Hasil penelitian ini didukung oleh penelitian terdahulu yang dilakukan oleh Yunita dan Mu'ah (2011) yang meneliti Pengaruh Kombinasi Senam Kaki dan aroma terapi Terhadap Peningkatan Sirkulasi Darah Kaki Pada Pasien Diabetes Melitus (Dm) Di Puskesmas Mantup Kecamatan Mantup Kabupaten Lamongan. Penelitian ini menyimpulkan bahwa ada pengaruh kombinasi senam kaki dan aroma terapi terhadap peningkatan sirkulasi darah kaki pada pasien Diabetes Melitus dengan nilai signifikansi untuk nilai ABPI $-4,958$ dan nadi $-4,397$ ( $<<0,000)$.
Pemeriksaan ABI dilakukan untuk mengetahui keadekuatan sirkulasi vaskuler perifer ke arah tungkai pada penderita diabetes. Pada pasien yang mengalami gangguan peredaran darah kaki maka akan ditemukan tekanan darah tungkai lebih rendah dibandingkan dengan tekanan darah lengan (Smeltzer \& Bare, 2010). Sirkulasi perifer area tungkai yang buruk merupakan salah satu faktor pemicu terjadinya ulkus kaki pada penderita diabetes, selain faktor neuropati dan infeksi (Ruff dalam Maulana, 2012).

Kombinasi senam kaki dengan aroma terapi menjadikan tubuh menjadi rileks dan melancarkan peredaran darah. Peredaran darah yang lancar akibat digerakkan dapat menstimulasi darah mengantar oksigen dan gizi lebih banyak ke sel-sel tubuh, serta membantu membawa racun lebih banyak untuk dikeluarkan (Natalia, Hasneli, \& Novayelinda, 2012).

Gerakan-gerakan kaki disertai pemberian aroma terapi yang dilakukan selama senam kaki diabetik sama halnya dengan pijat kaki yaitu memberikan tekanan dan gerakan pada kaki serta aroma terapi mempengaruhi hormon yaitu meningkatkan sekresi endorphin yang berfungsi untuk menurunkan sakit, vasodilatasi pembuluh darah sehingga terjadi penurunan tekanan darah terutama sistolik brachialis yang berhubungan langsung dengan nilai ABI (Laksmi, Agung, Mertha, \& Widianah, 2006).

Kombinasi senam kaki diabetes dengan aromaterapi juga digunakan sebagai latihan kaki dan relaksasi. Latihan kaki dan aromaterapi juga dipercaya untuk mengelola pasienyangmengalami DM, pasien DM setelah latihan kaki merasa nyaman, mengurangi nyeri, mengurangi kerusakan saraf dan mengontrol gula darah serta meningkatkan sirkulasi darah pada kaki (Taylor, 2010; Black \& Hawks, 2009).

Peranan intervensi kombinasi senam kaki DM dan aroma terapi sangat penting untuk terapi komplementer pada penderita DM tipe II karena gerakan gerakan senam kaki dan aroma terapi akan memberikan stimulus pada 
pembuluh darah dan dapat melancarkan aliran perifer. Penelitian ini sejalan dengan penelitian yang dilakukan oleh Julia Filly (2016) dengan judul Pengaruh Senam Kaki Diabetes dan Aroma Terapi Terhadap Perubahan nilai ABI Pada Pasien Diabetes Melitus Tipe 2 Di Wilayah Kerja Puskesmas Enemawira menunjukkan bahwa adanya pengaruh senam kaki diabetes terhadap perubahan nilai $A B I$ pada pasien diabetes mellitus tipe 2 diwilayah kerja puskesmas Enema wira dengan uji $t$ test paired samples test didapatkan nilai $\mathrm{p}=0,000<\mathrm{a}=$ 0,05 . Menurut Widiati \& Proverawati (2010) Senam kaki DM yang dikombinasikan dengan aroma terapi sangat berpengaruh sekali terhadap relaksasi dan kelancaran aliran perifer terutama pada daerah kaki. Dengan menggerakkan kaki dengan gerakan tertentu disertai dengan relaksasi dari aroma terapi maka akan menghasilkan reaksi seperti lancarnya aliran darah dan bermanfaat bagi otot-otot kaki sehingga resiko deformitas dan kekakuan otot bisa dicegah terutama bagi penderita DM.

Dengan demikian, dapat peneliti simpulkan bahwa kombinasi senam kaki diabetes dan aroma terapi efektif memperbaiki nilai $\mathrm{ABI}$, hal ini karena Latihan fisik merupakan salah satu prinsip dalam penatalaksanaan penyakit Diabetes Melitus. Senam kaki sendiri merupakan penatalaksanaa DM dengan pendekatan non farmakologi dalam mengatasi gejala kesemutan yang disebabkan karena gangguan sirkulasi darah kaki dan dapat memperlancar sirkulasi darah kaki. Hal ini disebabkan karena efek dari senam kaki yang dapat meningkatkan sirkulasi darah kaki. Dengan efek senam kaki dan faktor lain yang mempengaruhi, maka nilai ABPI dapat menjadi normal.

2. Analisis tingkat stress pada penderita diabetes mellitus sebelum dan sesudah dilakukan tindakan kombinasi senam kaki dan aromaterapi pada kelompok intervensi dan control

Dari table 5.3 diketahui bahwa, analisis statistik pre test dengan post test tingkat stress pada kelompok intervensi dengan menggunakan uji Wilcoxon diperoleh hasil $\mathrm{P}$ value 0.001 , lebih kecil dari $\alpha$ 0.05. Sementara itu analisis statistic pre test dengan post test tingkat stress pada kelompok kontrol dengan menggunakan uji Wilcoxon diperoleh hasil $\mathrm{P}$ value 0.444 . Dari hasil tersebut dapat disimpulkan bahwa Ho ditolak dan Hi diterima yang artinya ada pengaruh tindakan kombinasi senam kaki dan aromaterapi terhadap tingkat stress pada pasien diabetes mellitus.

Hal ini sesuai dengan penelitian yang dilakukan oleh Arwani dkk (2013), yang menyatakan bahwa terdapat pengaruh pemberian aromaterapi terhadap tingkat stress pasien dibetes mellitus di RS Tugu Semarang ( $\mathrm{p}<$ 0.05). Disarankan perlunya pemberian aromaterapi yang sesuai keinginan pasien guna menurunkan tingkat stress. Dampak positif kombinasi senam kaki dan aromaterapi terhadap penurunan tingkat stress ini disebabkan karena aromaterapi diberikan secara langsung (inhalasi) di sertai dengan gerakangerakan kaki yang mampu meningkatkan relaksasi. Mekanisme melalui penciuman jauh lebih cepat dibanding rute yang lain dalam penanggulangan problem emosionl seperti stess karena hidung / penciuman mempunyai kontak langsung dengan bagian-bagian otak yang bertugas merangsang terbentuknya efek yang ditimbulkan oleh aromaterapi (Koensoemardiyah, 2009).

Berdasarkan penelitian Karadag etall (2015) menyatakan bahwa studi ini menemukan bahwa minyak esensial lavender meningkat kualitas tidur dan mengurangi tingkat anxiety pada pasien dengan CAD. Di unit perawatan koroner, gangguan tidur dan kecemasan merupakan faktor penting yang mempengaruhi mengisi kesehatan pasien. Perawat memiliki mayor tanggung jawab karena mereka menghabiskan waktu lama dengan pasien. Sebagai alat yang tidak invasif, murah, dan mudah digunakan kabel, biaya perawatan, intervensi keperawatan independen dan sesuai untuk pasien jantung, lavender penting minyak dapat diterapkan di unit perawatan intensif.

Hal ini diperkuat oleh penelitian yang dilakukan oleh Winai Sayorwan 
(2012) dengan judul the effects of lavender inhalation on emotional states, autonomic nervous system, and brain electrical activity didapatkan hasil bahwa setelah diberikan aromaterapi lavender secara inhalasi responden mengalami relaksasai yang. Kelebihan dari kombinasi senam kaki dan aroma terapi gampang digunakan. Setelah terapi pasien akan merasakan relaksasi pada system persarafan dan lancarnya peredaran darah sehingga akan meningkatkan kenyamanan pasien (Kozier, 2010).

Maka dari itu dengan pemberian intervensi senam kaki kombinasi aroma terapi dapat menurunkan tingkat stress yang awalnya stress sedang menjadi stress ringan hal itu membuktikan bahwa dengan aroma terapi dengan adanya diberikan teknik aroma terapi pada kelompok kecil, responden dapat mengontrol stress dengan baik dan menjalani suatu tindakan dengan pikiran yang tenang dan dapat berkonsentrasi.

\section{KESIMPULAN DAN SARAN}

Simpulan

1. Senam kaki dan kombinasi aroma terapi dapat meningkatkan ABI pada pasien Diabetes Mellitus

2. Senam kaki kombinasi aroma terapi dapat menurunkan tingkat stress pada pasien Diabetes Mellitus

Saran

1. Bagi institusi pendidikan

Hasil penelitian ini dapatnya digunakan sebagai tambahan materi dalam proses belajar mengajar khususnya pada mata kuliah medical bedah dan keperawatan komplementer.

2. Bagi peneliti selanjutnya

Untuk dapatnya meneliti pengaruh relaksasi progresif terhadap penurunan gula darah pasien DM

3. Bagi puskesmas

Dapat dijadikan bahan acuan dalam meningkatkan mutu pelayanan bagi pasien diabetes mellitus.

4. Bagi sesama profesi perawat

Gunakan hasil penelitian ini sebagai informasi dan ilmu tentang pengaruh kombinasi senam kaki dan aromaterapi terhadap nilai $\mathrm{ABI}$ dan tingkat stress pada penderita diabetes mellitus.
DAFTAR PUSTAKA

Adiyati., 2010., Diabetes Melitus \& Penatalaksanaan Keperawatan. Yogyakarta : Nuha Medika.

Afrianti Wahyu Widiarti, Suhardi. ,2015., Penurunan Kecemasan Menghadapi Skripsi Dengan Menggunakan Aromaterapi Inhalasi. Jurnal Terpadu Ilmu Kesehatan. Di unduh $20 \quad$ Juli 2018 dari http://Afrianti.fk.@ub.ac.id

Arwani dkk., 2013., Pengaruh Pemberian Aromaterapi Terhadap Tingkat Stress Pasien Dibetes Mellitus di RS Tugu Semarang, Prosiding Konferensi Nasional Ppni Jawa Tengah 2013

Ayur Merdikawati, Titin Andri Wihastuti., 2015., Efektifitas Senam Kaki Diabetek dengan Tempurung Kelapa terhadap Tingkat Sensitivitas Kaki pada Pasien Diabetes Melitus Tipe 2. Program Studi Ilmu Keperawatan Riau

Black J.M., \& Hawks J.H., 2009., MedicalSurgical Nursing : Clinical Management for Positive out comes. 8Th Edition Singapore : Elseveir Saunders.

Koensoemardiyah., 2009., A-Z aromaterapi untuk kesehatan, kebugaran, dan kecantikan. Ed 1. Yogyakarta: Andi.

Kozier, et al., 2010., Fundamental Keperawatan. Jakarta : EGC

Laksmi, Agung, I. A., Mertha, I. M., \& Widianah, L., 2006., Pengaruh Foot Massage Terhadap Ankle Brachial Index (ABI) Pada Pasien DM Tipe 2 Di Puskesmas II Denpasar Barat. Journal Of Udayana.

\section{Maulana., 2012., Diabetes Melitus \& Penatalaksanaan Keperawatan. Yogyakarta : Nuha Medika.}

Natalia, N., Hasneli, Y., \& Novayelinda, R., 2012., Efektifitas senam kaki diabetik dengan tempurung kelapa terhadap tingkat sensitivitas kaki pada pasien diabetes melitus 2. Jom Unri, 1-9. 
Prima Dewi AP., 2013., Aromaterapi Lavender Sebagai Media Relaksasi, Bagian farmasi Fakultas Kedokteran Universitas Udayana

Proverawati, 2010. Senam Kaki DM. Yogyakarta: Muha Medika.

Romani, Hendarsih, Asmarani., 2012., p Analisis Faktor- Faktor Risiko Terjadi Ulkus Kaki pada Pasien Diabetes Melitus di RSUD Dr. Moewardi. Fakultas Ilmu Keperawatan Kekhususan Keperawatan Medikal Bedah Depok.

Soegondo, S., 2009., Farmakologi pada pengendalian glikemia diabetes mellitus tipe 2, dalam Sudoyo. Buku Ajar Ilmu Penyakit Dalam. (3rd Ed.). Jakarta: Pusat Penerbit Departemen Penyakit Dalam FKUI

Yunita dan Mu'ah., 2011., Pengaruh Kombinasi Senam Kaki dan aroma terapi Terhadap Peningkatan Sirkulasi Darah Kaki Pada Pasien Diabetes Melitus (Dm) Di Puskesmas Mantup Kecamatan Mantup Kabupaten Lamongan. Jurnal Biomedik, 7(November), 2011. 